\title{
THE RELATIONSHIP BETWEEN LEADERSHIP BEHAVIOUR, OUTCOMES OF LEADERSHIP AND EMOTIONAL INTELLIGENCE
}

\author{
C COETZEE \\ P SCHAAP \\ pschaap@hakuna.up.ac.za \\ Department of Human Resources Management \\ University of Pretoria
}

\begin{abstract}
The aim of the study was to explore relationship between leadership behaviour, the outcomes of leadership and the emotional intelligence of managers. The "Multifactor Emotional Intelligence Scale" and the "Multifactor Leadership Questionnaire" were applied to a convenience sample of 100 managers working for various companies in South Africa. The study yielded significant correlations between managers' level of emotional intelligence, leadership behaviour and the outcomes of leadership.
\end{abstract}

\section{OPSOMMING}

Die doel van die studie was om die verband tussen die leierskapsgedrag, uitkoms van leierskap en die emosionele intelligensie van bestuurders te ondersoek. Die "Multifactor Emotional Intelligence Scale" en die "Multifactor Leadership Questionnaire" is op 'n gerieflikheidsteekproef van 100 bestuurders wat in verskeie organisasies in SuidAfrika werksaam is, toegepas. Die resultate dui op 'n beduidende korrelasie tussen die vlak van emosionele intelligensie, leierskapsgedrag en die uitkoms van leierskap van bestuurders.

In the $21^{\text {st }}$ century, managers and leaders are expected to cope in and with a rapidly changing world of work (Lewis, Goodman \& Fandt, 1998). This rapid change, or Hyperchange, as defined by Lewis et al. (1998, p. 14) is a "condition of rapid, dramatic, complex and unpredictable change that has a significant effect on the ways in which organizations are managed". Organisations have changed to a flatter structure where managers and leaders empower their employees and entrust them with more and more responsibility (Hooper \& Potter, 2000). This has also resulted in a fundamental shift in leadership behaviour since the early 1990s (Hooper \& Potter, 2000). A more democratic style of leadership and management is required where openness and accountability is exercised - a leadership behaviour which is effective at all levels and is based on trust (Hooper \& Potter, 2000).

Lewis et al. (1998) assert that the managers of the future will have to be prepared to cope with change if they are to be effective. They will require abilities such as being teamoriented, strong communicators, team players, problemsolvers, change-makers and leaders (Lewis et al., 1998). Managers will have to be competent leaders in order to transform their people to achieve the required company outcomes (Hooper \& Potter, 2000). Ryback (1998) describes a 21 st century leader as having the ability to demonstrate a greater empathy and concern for people issues than his/her earlier counterparts.

A leader will have to play various roles within this new, changing environment (Drucker, 1996; Nanus, 1992; Lewis et al., 1998). To ensure that change takes place successfully, greater consideration for the individual should be instilled in leaders with regard to aspects such as understanding how people view the world (Hooper \& Potter, 2000). The importance of structures, programmes and processes should not be disregarded, but people are the programmers of these programmes (Drucker, 1996, p.153).

The realisation that the knowledge, skills and experience of people are fundamental to the success of an organisation has resulted in the expectation that leaders of the future will need to pay more attention to developing the "people" aspect of the organisation (Steers, Bigley \& Porter, 1996). Leadership then takes into account both the emotional attributes and the rational

Requests for copies should be addressed to: P Schaap, Pieter.schaap@up.ac.za aspects of every individual (Steers et al., 1996). In this regard, management is beginning to realize the importance of emotional intelligence in improving organisational effectiveness (Bliss, 2000). An emotionally intelligent leader focuses on the shared values, training and development of his/her followers and is able to instill vision and purpose (Colvin, 1999). In the conclusion of his study on emotional intelligence and a leader's ability to make effective decisions, Bliss (2000) states that a leader has to have emotional intelligence in order to motivate his/her followers to achieve company outcomes.

Weisinger (1998) refers to emotional intelligence as the intelligent use of emotions. According to Weisinger (1998), this allows one to use emotions to guide behaviour and thinking in ways that will enhance results. According to Caruso, Mayer and Salovey (2002), successful leaders need the ability to be aware of their own feelings and emotions, but also to identify accurately the emotions of the group and of individual followers. Ryback (1998) asserts that to be able to manage or lead others successfully, a leader must be able to read their emotions. Doing this well will allow the leader to gain others' trust and loyalty, and as a result, improve organisational performance (Ryback, 1998). This view is supported by other researches, who agree that this is one of the most important abilities the "new leader" should have (Drucker, 1996; Hooper \& Potter, 2000; Steers et al., 1996; Steiner \& Perry, 1999; Swart, 1985; Weisinger, 1998). The emotional ability dimension of intelligence has previously been overlooked, but is now regarded as an area of ability critical to human functioning and managing people effectively (Caruso et al. 2002; Ryback, 1998; Weisinger, 1998; Steiner \& Perry, 1999).

A study conducted at the Johnson \& Johnson Consumer Care and Personal Care Group has shown that the highest performing managers have significantly more emotional intelligence than other managers (Cavallo, 2000). Bliss (2000) concluded in his study on emotional intelligence and a leader's ability to make effective decisions that emotional intelligence plays a significant role in a managers' ability to motivate followers to achieve company outcomes. The research thus suggests that there is a significant relationship between leadership and emotional intelligence.

\section{Objective}

The main objective of this study was to explore the relationship between leadership behaviour, the outcomes of leadership and the emotional intelligence of managers. 


\section{METHOD}

Sample

A sample of two hundred and fifty $(\mathrm{N}=250)$ managers was selected from South African companies, using the convenience sampling method. The managers were required to complete the forms in an uncontrolled environment. A total of $100(\mathrm{~N}=100)$ managers (42 males and 58 females) returned their questionnaires. The average age for the group was 36; the youngest respondent was 22 years and the oldest respondent was 63 years of age. The statistics for the sample group are set out in Table 1. In total, 92 individuals indicated their educational level. Of these, $18 \%$ had obtained a diploma, $41 \%$ had obtained a degree or higher diploma and 33\% had obtained a post-graduate qualification. In terms of their management level, $31 \%$ of the respondents indicated that they were at a junior management level, $42 \%$ of the respondents indicated a middle management level, $20 \%$ of the respondents indicated a senior management level and $6 \%$ of the respondents indicated a top management level. The sample consisted of predominantly white respondents (99) and one coloured respondent. In terms of home language, the sample consisted mostly of Afrikaans-speaking respondents (86\%), followed by English-speaking respondents (13\%). One percent of the respondents indicated "other" as their home language. The selected managers' average number of years of work experience and management experience was 14 years and seven years respectively.

TABLE 1

SAMPLe STATISTICS

Frequency Percentage Valid Cumulative PercentagePercentage

\section{Qualification}

Valid

Diploma

B-Degree \& Higher Diploma

Honours degree Master's degree Doctorate Total

Missing values

Total

Management level

18,00

19,57

44,57

19,57

41

41,00

25,00

7,61

3,26

100,00

8,00

100,00

$$
\begin{gathered}
31,00 \\
42,00 \\
20,00 \\
6,00 \\
99,00 \\
1,00 \\
100,00
\end{gathered}
$$

100

\section{1,31 \\ 42,42 \\ 20,20 \\ 6,06 \\ 100,00}

31,31

73,74

93,94
Valid

Junior management
Middle management
Senior management
Top management
Total
vlues

Missing value

Total

Race

Valid

Coloured

White

Total

99

100

100,00

.

Language

Valid

Afrikaans
English
Other

Total

Gender

Valid
Male
Female
Total

1
99
100

1
99

1

99

100

1

100

86

99

100

100

\begin{tabular}{cc}
42 & 42 \\
58 & 100 \\
100 & \\
\hline
\end{tabular}

Measuring instruments

Emotional intelligence

The Multifactor Emotional Intelligence Scale (MEIS) is an ability test which measures four branches of Emotional Intelligence, as defined by Mayer and Salovey (1997). It takes an hour to complete. The participants are required to read a scenario and rate each of five defined reactions according to how well the reaction describes the emotion depicted in the scenario on a proximity interval scale (for example, 1 = "Definitely does not describe"; 5 = "Definitely does describe"). The MEIS measure of emotional intelligence is divided into four classes or branches of abilities and is illustrated in Table 2 (Mayer, Salovey \& Caruso, 2000)

\section{TABLE 2}

THE FOUR-BRANCH ABILITY MODEL AND MEASURES OF EMOTIONAL INTELLIGENCE

\begin{tabular}{l}
\hline Branch of Ability \\
\hline Test 1: Identify Emotions (138 items) \\
Test 2: Using Emotions (76 items) \\
\begin{tabular}{ll} 
Test 3: Understanding Emotions (80 items) \\
Test 4: Managing Emotions & $\begin{array}{l}\text { Subtest 1: Managing Emotions in } \\
\text { (48 items) }\end{array}$ \\
& $\begin{array}{l}\text { Subtest 2: Managing Emotions in Self } \\
\text { (24 items) }\end{array}$ \\
\hline
\end{tabular}
\end{tabular}

The MEIS obtained a full-scale alpha reliability of $\alpha=0,96$ (Mayer et al., 2000).

Identifying Emotions refers to the ability to recognize how a person and those around him/her feel. It is measured through the individual's emotional perception of emotion in faces, designs and stories (Mayer et al., 2000). According to Weisinger (1998), Identifying Emotions also indicates the ability to accurately perceive, appraise and express emotion.

Using Emotions focuses on the ability to generate an emotion, and then reason in view of this emotion. This measure expects the person to generate a certain emotional state and use that emotion to solve a problem (Mayer et al., 2000). Weisinger (1998) describes using emotion as having the ability to access and generate feelings on demand when they can facilitate understanding of oneself and another person (Mayer et al., 2000).

Meyer et al. (2000) describe Understanding Emotions as the ability to understand complex emotions and emotional chains, for example, how emotions shift from one stage to another. Alternatively, Weisinger (1998) describes Understanding Emotions as having the ability to understand the knowledge that is derived from emotions. This measure expects the respondent to indicate which simple emotions form a more complex emotion and how emotions change into stronger emotions. Understanding Emotions tests the respondents' knowledge of the consequences of having an emotion and acting on that emotion, and their understanding of the conflicting and complex emotions of two people in an emotional event (Mayer \& Salovey, 1997).

Managing Emotions allows one to manage emotion in oneself and others (Mayer et al., 2000). Managing Emotions also means the ability to regulate emotions and promote emotional and intellectual growth. In Managing emotions in Others the respondent has to indicate what would be considered effective action to cope with the emotion in a story. In Managing emotions in the Self, the respondent is expected to indicate how effective each action would be to 
cope with emotions in a situation in which he/she is involved (Mayer \& Salovey, 1997).

\section{Transformational and transactional leadership}

The Multifactor Leadership Questionnaire (MLQ5X-short) is a 45-item questionnaire which measures the full range of leadership behaviours (Bass \& Avolio, 1997). The participants are expected to read a scenario and then rate how well it describes their own leadership behaviour on a proximity interval scale (for example, $0=$ "Not at all"; $4=$ "Frequently, if not always").

The Multifactor Leadership Questionnaire in its various forms has acceptable validity and reliability and has been used extensively worldwide. The MLQ has proven to be a strong predictor of leader performance across a broad range of organizations (Bass \& Avolio, 1994). According to Hanke (1998), the alpha reliability coefficients for the MLQ scales varies between $\alpha=0,71$ and $\alpha=0,93$. Similar reliabilities were reported by Ackermann, Schepers, Lessing and Dannhauser (2000) on the MLQ (Form 5R) in the South African context and ranged from $\alpha=0,74$ to $\alpha=0,94$. In a more recent analysis, Bass and Avolio (2000) report reliabilities for each of the MLQ 5X scales ranging from $\alpha=0,74$ to $\alpha=0,91$.

TABLE 3

THE LEADERSHIP FACTORS EVALUATED IN THE MLQ5X MEASURING INSTRUMENT

\begin{tabular}{|c|c|}
\hline Transformational Leadership & Transactional Leadership \\
\hline Idealised Influence (8 items) & Contingent Reward (4 items) \\
\hline Inspirational Motivation (4 items) & Management by Exception \\
\hline Intellectual Stimulation (4 items) & (Active) (4 items) \\
\hline $\begin{array}{l}\text { Individualised Consideration } \\
\text { (4 items) }\end{array}$ & $\begin{array}{l}\text { Management by Exception } \\
\text { (Passive) ( } 4 \text { items) }\end{array}$ \\
\hline Non-Transactional Leadership & Outcomes of Leadership \\
\hline \multirow[t]{3}{*}{ Laissez-faire (4 items) } & Extra Effort (3 items) \\
\hline & Effectiveness (3 items) \\
\hline & Satisfaction (3 items) \\
\hline
\end{tabular}

In their model of Transactional and Transformational Leadership, Bass and Avolio (1993) describe four elements of Transformational Leadership behaviour and three elements of Transactional Leadership behaviour respectively (Bass, 1985). Transactional Leadership is viewed as being complementary to Transformational Leadership as it forms the basis for carrying out the required tasks (Liontos, 1992). According to Bass (1985), two essential elements of Transactional Leadership are "Contingent Reward" and "Management by Exception". These factors are described below:

Contingent Reward: leaders encourage the performance of their subordinates by rewarding them. This reward is contingent or appropriate according to performance level (Steers et al., 1996). Leaders first need to understand precisely what their goals are and then define and communicate to followers the work that must be done to achieve these goals. Thereafter, followers are rewarded according to the extent to which work is completed successfully (Bass, 1985; Kuruppuarachchi, 2001).

Management by Exception: employees are motivated and directed to achieve expected standards of performance (Bass, 1985; Kuruppuarachchi, 2001). Leaders who search for potential deviations from rules and standards and take corrective action can be seen as actively managing by exception. Passive management by exception refers to leaders' only taking action once standards are not met (Robbins, 1998).

A Non-transactional or Laissez-faire leader abdicates responsibility and avoids making decisions (Robbins, 1998).
Such a leader is indifferent to the progress and or development of an individual follower, and thus distances him/herself from and does not interfere with the efforts of a follower (McLeod \& Hanks, 1984). Bass (1985) describes a Laissez-faire leader as a passive leader who waits for followers to report on deviations from standards, and does not actively monitor the performance of followers.

The Transformational Leadership factors can be referred to as the four I's of leadership, namely: Idealised Influence, Inspirational Motivation, Intellectual Stimulation and Individualized Consideration (Bass, 1985). These factors are defined below.

Individualized Consideration: leaders consider employees as individuals and devote personal attention to them. This then assists followers to rise to higher levels of achievement (Kuruppuarachchi, 2001; Bass \& Avolio, 1992).

Intellectual Stimulation: this involves the encouragement of critical thinking, creativity and an analysis of new perspectives (Kuruppuarachchi, 2001). Such a leader also allows the follower to think for him/herself, and to solve problems in unique ways (Bass \& Avolio, 1992).

Inspirational Motivation: this involves inspiring followers through goal-setting, visionary behaviour and role modelling by other inspirational leaders (Kuruppuarachchi, 2001). Bass and Avolio (1992) assert that this rouses followers towards a sense of purpose and meaning. Such a leader creates vision and commitment.

Idealised Influence: this means showing respect for others and building their confidence and trust in the overall mission. This creates a sense of enthusiasm in individuals and allows them to work actively together towards a goal (Bass \& Avolio, 1992).

Outcomes of Leadership refer to the extra effort employees are willing to invest in order to achieve set goals. It also refers to the leaders' ability to make the effort of their followers more meaningful, which in turn creates follower satisfaction (Steers et al. 1996). The effectiveness of a leader in creating personal commitment by increasing the intrinsic value of efforts and linking this to a follower's self-concept increases the probability that these values will turn to action (Steers et al. 1996).

\section{Statistical analysis}

The relationship between leadership behaviour, the outcomes of leadership and emotional intelligence was explored by computing Pearson correlation coefficients and by means of principal component and multiple regression analysis. The SPSS statistical software was used for this purpose.

\section{RESULTS}

Correlation coefficients were calculated between the MLQ5X variables and the MEIS variables. Table 4 highlights the correlations between specific leadership behaviours and outcomes and the variables of emotional intelligence.

The results in Table 4 (above) highlight a statistically significant positive correlation between Transformational Leadership and the full-scale Emotional Intelligence scores $(r=$ $0,274 ; p \leq 0,05)$, which can mainly be attributed to the subscales Identifying Emotions $(r=0,217 ; p \leq 0,05)$ and Managing Emotions $(r=0,299, p \leq 0,01)$. Transactional Leadership $(r=$ $0,213 ; p \leq 0,05)$ correlated statistically significantly with Managing Emotions. A statistically significant negative correlation was obtained between Non-transactional Leadership and Using Emotions $(r=-0,202 ; p \leq 0,05)$. The reliability coefficients for the sub-scales included in Table 4 were between $\alpha=0,57$ and $\alpha=0,92$. 
TABLE 4

CORRELATION BETWEEN LEADERSHIP BEHAVIOUR AND THE INDICATORS OF EMOTIONAL INTELLIGENCE

$\mathrm{N}=100$

$\begin{array}{ccc}\text { Transformational Transactional } & \text { Non-Trans- } \\ \text { Leadership } & \text { Leadership } & \text { actional } \\ (\alpha=, 80) & (\alpha=, 57) & \text { Leadership } \\ & & (\text { Laissez-faire }) \\ & & (\alpha=, 57)\end{array}$

\begin{tabular}{lccc}
\hline $\begin{array}{l}\text { Identifying Emotions } \\
(\alpha=, 92)\end{array}$ & $0,217^{*}$ & $-0,165$ & $-0,032$ \\
$\begin{array}{l}\text { Using Emotions } \\
\left(\begin{array}{l}\alpha=, 88) \\
\text { Understanding Emotions } \\
(\alpha=, 66)\end{array}\right.\end{array}$ & 0,118 & $-0,161$ & $-0,202^{*}$ \\
$\begin{array}{l}\text { Managing Emotions } \\
\begin{array}{l}\alpha=, 80) \\
\text { Full-scale Emotional Intelligence } 0,274^{*}\end{array}\end{array}$ & $-0,137$ & $-0,050$ \\
\begin{tabular}{l}
$\alpha=, 92)$ \\
\hline
\end{tabular} & $0,299^{* *}$ & $0,213^{*}$ & $-0,066$ \\
\end{tabular}

${ }^{*} \mathrm{p}<0,05$

$* * \mathrm{p}<0,01$

Table 5 provides a more detailed analysis of the subscales underlying the main tests of the MLQ5X. The results in Table 5 indicate statistically significant correlations between the ability measures of Emotional Intelligence and MLQ5X subscales.

The alpha reliabilities of the MLQ5X for the research group were significantly lower than expected, at reliabilities between $\alpha=0,35$ and $\alpha=0,80$. The MEIS obtained an acceptable full-scale alpha reliability of $\alpha=0,92$, with sub-scale alpha reliabilities of between $\alpha=0,66$ and $\alpha=0,92$.

The Transformational Leadership subscale - Idealised Influence (behaviour) correlated statistically significantly with Identifying Emotions $(r=0,232 ; p \leq 0,05)$. Various Transformational Leadership subscales and one Transactional Leadership subscale had a statistically significant positive correlation with Managing Emotions. These subscales are Inspirational Motivation $(r=0,280 ; p \leq 0,01)$, Intellectual Stimulation $(r=0,229 ; p \leq 0,05)$, Individualized Consideration $(r=0,204 ; p \leq 0,05)$ and Contingent Reward $(r=0,283 ; p \leq 0,05)$. The correlations between the Transformational Leadership subscales and Managing Emotions in Others subscale were as follows: Inspirational Motivation $(r=0,286 ; p \leq 0,01)$, Intellectual Stimulation $(r=0,238 ; p \leq 0,05)$, Individualized Consideration $(r=0,232 ; p \leq 0,05)$ and Contingent Reward $(r=0,244 ; p \leq 0,05)$. The Outcomes of Leadership subscale, Extra Effort, yielded a statistically significant positive correlation $(r=0,284 ; p \leq 0,01)$ with Managing Emotions, and more specifically, Managing Emotions in Others $(r=0,330 ; p \leq 0,05)$. In addition, Satisfaction had a statistically significant positive correlation with Managing Emotions in Others $(r=0,201 ; p \leq 0,05)$.

Management by Exception (Passive) had a statistically significant negative correlation with Identifying Emotions $(r=-0,220$ $p \leq 0,05)$, Using Emotions $(r=-0,275 ; p \leq 0,01)$ and Understanding Emotions $(r=-0,316 ; p \leq 0,01)$. Laissez-Faire leadership behaviour had a statistically negative correlation with Using Emotions $(r=-0,202 ; p \leq 0,05)$. Other correlations were non-significant.

There were statistically significant positive correlations between the full-scale Emotional Intelligence scores and the subscales of Transformational Leadership - Idealised Influence $(r=0,244$; $p \leq 0,05)$ and Individualised Consideration $(r=0,226 ; p \leq 0,05)-$ nand one Transactional Leadership subscale, namely Contingent Reward $(r=0,231 ; p \leq 0,05)$. There was a statistically significant negative correlation between the Transactional Leadership subscale Management by Exception (Passive) and the full-scale Emotional Intelligence scores $(r=-0,328 ; p \leq 0,01)$. All other correlations were non-significant.

Principal component analysis was performed to determine the underlying second order structure of the MLQ5X variables in respect of the research sample. Figure 1 and Table 6 provide the results of the factor analysis of the MLQ5X. The sample size was adequate, according to the Kaiser-Meyer-Olkin measure of sampling adequacy $(0,784)$ (Kim \& Mueller, 1978). Three components were greater than unity and accounted for $58,794 \%$ of the total variance. With reference to Figure 1, two components were identified as significant, based on Horn's (1965) criteria. The eigenvalues of a random data set (the broken line) intersect the eigenvalues of the true data set (the solid line) between roots two and three, indicating two significant components. The results reported in Table 6 indicate that the two significant components explain $48,56 \%$ of the total variance. The Direct Oblimin rotation method was used, as the

TABLE 5

CORRELATIONS BETWEen THE VARIABLES OF THE MLQX5 AND THE MEIS

\begin{tabular}{|c|c|c|c|c|c|c|c|c|c|c|c|c|}
\hline & $\begin{array}{c}\text { Idealised } \\
\text { Influence } \\
\text { Attribute } \\
(\alpha=, 51)\end{array}$ & $\begin{array}{c}\text { Idealised } \\
\text { Influence } \\
\text { Behaviour } \\
(\alpha=, 57)\end{array}$ & $\begin{array}{c}\text { Inspira } \\
\text { tional } \\
\text { Motivation } \\
(\alpha=, 70)\end{array}$ & $\begin{array}{c}\text { Intellect, } \\
\text { Stimu } \\
\text { lation } \\
(\alpha=, 36)\end{array}$ & $\begin{array}{l}\text { Indiv, - } \\
\text { Consi } \\
\text { deration } \\
(\alpha=, 49)\end{array}$ & $\begin{array}{l}\text { Contin- } \\
\text { gent } \\
\text { Reward } \\
(\alpha=, 35)\end{array}$ & $\begin{array}{c}\text { Manage } \\
\text { by } \\
\text { Exception } \\
(\text { Active) } \\
(\alpha=, 68)\end{array}$ & $\begin{array}{c}\text { Manage } \\
\text { by } \\
\text { Exception } \\
\text { (Passive) } \\
(\alpha=, 57)\end{array}$ & $\begin{array}{c}\text { Laissez- } \\
\text { faire } \\
(\alpha=, 57)\end{array}$ & $\begin{array}{c}\text { Extra } \\
\text { Effort } \\
(\alpha=, 72)\end{array}$ & $\begin{array}{c}\text { Effective- } \\
\text { ness } \\
(\alpha=, 51)\end{array}$ & $\begin{array}{c}\text { Satis- } \\
\text { faction } \\
(\alpha=, 58)\end{array}$ \\
\hline $\begin{array}{l}\text { Identifying Emotions } \\
(\alpha=, 92)\end{array}$ & 0,111 & 0,232 * & 0,150 & 0,134 & 0,147 & 0,156 & $-0,190$ & $-0,220^{*}$ & $-0,032$ & 0,081 & $-0,028$ & 0,000 \\
\hline $\begin{array}{l}\text { Using Emotions } \\
(\alpha=, 88)\end{array}$ & 0,050 & 0,135 & 0,032 & 0,088 & 0,132 & 0,050 & $-0,067$ & $-0,275^{* *}$ & $-0,202$ * & 0,017 & $-0,058$ & $-0,062$ \\
\hline $\begin{array}{l}\text { Understanding Emotions } \\
(\alpha=, 66)\end{array}$ & 0,151 & 0,115 & 0,063 & 0,013 & 0,137 & 0,142 & $-0,052$ & $-0,316^{* *}$ & $-0,050$ & 0,077 & 0,031 & 0,085 \\
\hline $\begin{array}{l}\text { Man,aging Emotions in Others } \\
(\alpha=, 51)\end{array}$ & 0,193 & 0,194 & 0,286 * * & $0,238^{*}$ & $0,232^{*}$ & $0,244^{*}$ & 0,116 & $-0,034$ & $-0,063$ & $0,330^{*}$ & 0,121 & 0,201 * \\
\hline $\begin{array}{l}\text { Man,aging Emotions in Self } \\
(\alpha=, 84)\end{array}$ & 0,101 & 0,026 & 0,135 & 0,107 & 0,030 & $0,223^{*}$ & 0,143 & 0,069 & $-0,029$ & 0,090 & 0,066 & $-0,005$ \\
\hline $\begin{array}{l}\text { Managing Emotions } \\
(\alpha=, 92)\end{array}$ & 0,186 & 0,168 & 0,280 * * & 0,229 * & $0,204^{*}$ & $0,283^{*}$ & 0,140 & 0,006 & $-0,066$ & $0,284^{* *}$ & 0,125 & 0,156 \\
\hline $\begin{array}{l}\text { Full-scale Emotional } \\
\text { Intelligence }(\alpha=, 92)\end{array}$ & 0,182 & $0,244^{*}$ & 0,179 & 0,149 & $0,226^{*}$ & 0,231 * & $-0,090$ & $-0,328$ * * & $-0,109$ & 0,162 & 0,020 & 0,070 \\
\hline
\end{tabular}

* $\mathrm{p} \leq 0,05$

** $\mathrm{p} \leq 0,01$ 
MLQ5X variables can be considered related. The quality of the principal component solution was evaluated using the level of interpretability and the simplicity of the structure obtained. The two-component solution (see Table 7) was well defined and yielded a simple structure, thereby providing a plausible principal component solution.

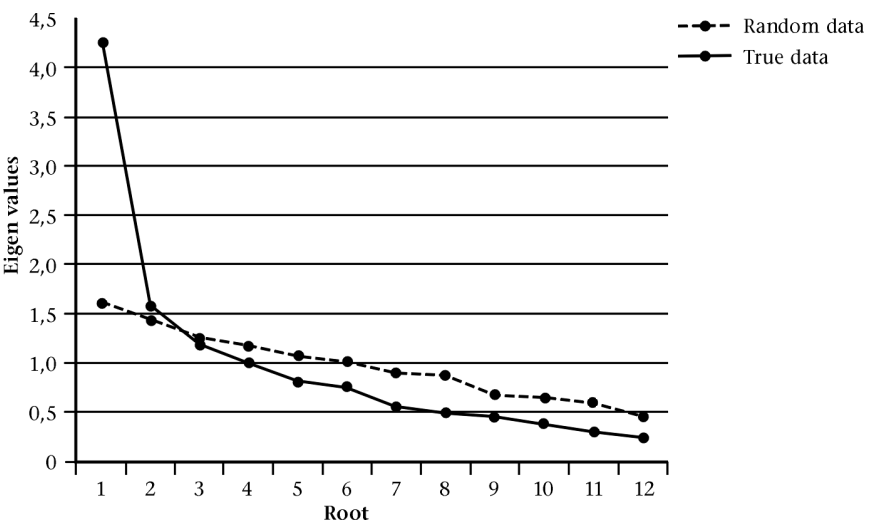

Figure 1: Scree-plot (MLQ)

TABLE 6

FACTOR EIGENVALUES AND VARIANCE EXPLAINED FOR THE MLQ5X

\begin{tabular}{|c|c|c|c|}
\hline \multirow[b]{3}{*}{ Component } & \multicolumn{2}{|c|}{ Total Variance Explained } & \multirow[b]{3}{*}{ Cumulative $\%$} \\
\hline & & Initial Eigenvalue & \\
\hline & Total & $\%$ of Variance & \\
\hline 1 & 4,202 & 35,016 & 35,016 \\
\hline 2 & 1,628 & 13,570 & 48,586 \\
\hline 3 & 1,225 & 10,208 & 58,794 \\
\hline 4 & 0,987 & 8,224 & 67,018 \\
\hline 5 & 0,799 & 6,659 & 73,677 \\
\hline 6 & 0,754 & 6,284 & 79,961 \\
\hline 7 & 0,540 & 4,496 & 84,457 \\
\hline 8 & 0,490 & 4,086 & 88,543 \\
\hline 9 & 0,434 & 3,617 & 92,160 \\
\hline 10 & 0,392 & 3,265 & 95,426 \\
\hline 11 & 0,301 & 2,510 & 97,936 \\
\hline 12 & 0,248 & 2,064 & 100,000 \\
\hline
\end{tabular}

Component 1 in the two-component solution consists of the subscales Individualized Consideration, Intellectual Stimulation, Inspirational Motivation, Idealised Influence, Contingent Reward, Extra Effort, Effectiveness and Satisfaction. Component 1 demonstrated an acceptable alpha scale reliability of $\alpha=0,88$. In Component 1 , what is known as effective leadership in the 21st century is portrayed, and it consists of Transformational Leadership combined with Contingent Reward and related Extra Effort, Effectiveness and Satisfaction of followers. Component 1 resembles leadership where openness, empowerment and accountability are exercised - leadership which, according to Hooper and Potter (2000), is effective at all levels within a rapidly changing world. Effective leaders in the 21st century demonstrate high levels of charisma, instill vision, motivate and inspire, focus on people, establish voluntary commitment, transform people to higher levels of performance, communicate trust and emotional support, and influence behaviour (Steers et al. 1996; Hooper \& Potter, 2000; Drucker, 1996; Swart, 1985). The observed shared variance in Component 1 can be attributed to what is called "relationship or people orientation" with specific emphasis on the active involvement and empowerment of people. Close and active collaboration between leaders and individuals is emphasised here. (For the purposes of this article, Component 1 is referred to as "Effective Leadership".)

TABLE 7

ROTATED PATTERN MATRIX FOR THE MLQ5X

\begin{tabular}{lcc}
\hline Pattern Matrix & \multicolumn{2}{c}{ Component } \\
& $\begin{array}{l}1 \\
\end{array}$ & 2 \\
& 0,668 & $(\alpha=, 62)$ \\
\hline Individualized Influence (Attribute) & 0,564 & 0,138 \\
Individualized Influence (Behaviour) & 0,770 & 0,013 \\
Inspirational Motivation & 0,576 & 0,000 \\
Intellectual Stimulation & 0,665 & $-0,157$ \\
Individualized Consideration & 0,640 & 0,304 \\
Contingent Rewards & 0,239 & 0,503 \\
Management by Exception (Active) & $-0,157$ & 0,716 \\
Management by Exception (Passive) & $-0,167$ & 0,840 \\
Laissez-Faire & 0,806 & $-0,066$ \\
Extra Effort & 0,651 & $-0,140$ \\
Effectiveness & 0,683 & $-0,076$ \\
Satisfaction & & \\
\hline
\end{tabular}

Component 2 is a combination of Management by Exception (Active) and Management by Exception (Passive) and Laissezfaire leadership behaviour. The highest loadings were on the Management by Exception (Passive) and Laissez-faire leadership behaviours. Management by Exception emphasises controlling performance according to set standards, while Laissez-faire emphasises an abdication of responsibility. Component 2 demonstrated an alpha scale reliability of $\alpha=$ 0,62 . The underlying factor that explains the observed shared variance in Component 2 appears to be a non-people orientation with particular emphasis on the element of passivity that leaders demonstrate towards the empowerment and involvement of individuals. Leaders appear to distance themselves from individual followers within the context of management by exception and Laissez-faire behaviour. (For the purposes of this article, Component 2 is called "Ineffective Leadership".)

Component 2 relates strongly to traditional managerial behaviour rather than to leadership as such. The focus is strictly on the means to getting tasks done while excluding the human factor that forms part of effective leadership in general.

Support for the notion of effective and ineffective leadership is provided by Lowe, Kroeck and Sivasubramaniam (1996), who performed 33 independent empirical studies using the Multifactor Leadership Questionnaire (MLQ). They concluded that there was a strong positive correlation between all the components of transformational leadership and both objective and subjective measures of performance. They obtained strong correlations between the Contingent Reward subscale and the subjective measure of performance. Very low to negative correlations were obtained for management by exception and both objective and subjective measures of performance.

Barbuto and Brown (2000) distinguish between what can be considered effective and ineffective leadership behaviour, as measured by the MLQ. Laissez-faire behaviour is considered least effective, followed by Management by Exception. Both can 
generally be considered ineffective leadership behaviour, as they often relate to high employee turnover and absenteeism, poor satisfaction and poor perception of organizational effectiveness over the long term. Contingent Rewards can be considered effective leadership behaviour, but leaders will not get more than they bargained for when practising this type of leadership behaviour. The remaining four leadership behaviours Individualised Consideration, Intellectual Stimulation, Inspirational Motivation and Individualised Influence - have all resulted in extra effort from workers, lower turnover, lower absenteeism and greater organizational adaptability to changes in the environment.

The principal component analysis of the MEIS scales resulted in a uni-dimensional construct. As indicated in Table 8, only the first component has an eigenvalue $(1,867)$ greater than unity and explains $46,672 \%$ of the total variance. The component matrix (see Table 9) shows that all four MEIS scales had high loadings on the first component. Thus, the validity of the MEIS full-scale score as an overall measure of emotional intelligence has been confirmed for the sample group.

TABLE 8

FACTOR EIGENVALUES AND VARIANCE EXPLAINED FOR THE MEIS

\begin{tabular}{|c|c|c|c|}
\hline \multirow[b]{3}{*}{ Component } & \multicolumn{2}{|c|}{ Total Variance Explained } & \multirow[b]{3}{*}{ Cumulative \% } \\
\hline & & Initial Eigenvalue & \\
\hline & Total & $\%$ of Variance & \\
\hline 1 & 1,867 & 46,672 & 46,672 \\
\hline 2 & 0,849 & 21,214 & 67,886 \\
\hline 3 & 0,709 & 17,726 & 85,612 \\
\hline 4 & 0,576 & 14,388 & 100,000 \\
\hline
\end{tabular}

TABLE 9

COMPONENT MATRIX FOR THE MEIS

Pattern Matrix

\begin{tabular}{c}
$\begin{array}{c}\text { Component } \\
1 \\
(\alpha=, 92)\end{array}$ \\
\hline 0,696 \\
0,719 \\
0,754 \\
0,544 \\
\hline
\end{tabular}

The relationship between emotional intelligence and the indicators of effective leadership and ineffective leadership as measured in this study was explored further by means of multiple regression analysis. Effective Leadership and Ineffective Leadership were treated as independent variables and full scale Emotional Intelligence as the dependent variable. The results of regression analysis that was performed to determine the relationship between Effective Leadership and Ineffective Leadership and Emotional Intelligence are illustrated in Table 10

According to Table 10, the leadership (effective or ineffective) demonstrated by a leader points towards his/her level of emotional intelligence. There was a significant correlation between the Emotional Intelligence scores and the Effective and Ineffective Leadership scores $(\mathrm{R}=, 342 ; \mathrm{p} \leq 0,01)$ of the sample group. Effective Leadership was significantly positively related $(\mathrm{t}=2,359 ; \mathrm{p} \leq 0,05)$ to Emotional Intelligence and Ineffective Leadership was significantly negatively related $(t=-2,645 ; p \leq 0,01)$ to Emotional Intelligence. The correlation
( $\mathrm{R}=0,342$ ) between the MLQ5X and MEIS scales has a medium effect size and can be considered of practical significance in terms of Cohen's, (1977) criteria. The conclusion can be drawn that a significant relationship does exist between emotional intelligence and what can be considered effective and ineffective leadership.

TABLE 10

REGRESSION ANALYSIS RESULTS INDICATING THE RELATIONSHIP BETWEEN EMOTIONAL INTELLIGENCE AND LEADERSHIP (EFFECTIVE AND INEFFECTIVE)

\begin{tabular}{|c|c|c|c|c|c|}
\hline \multicolumn{6}{|c|}{ Model Summary } \\
\hline & & $\mathbf{R}$ & R Square & $\begin{array}{l}\text { Adjusted } \\
\text { R Square }\end{array}$ & $\begin{array}{l}\text { Std Error } \\
\text { of the } \\
\text { Estimate }\end{array}$ \\
\hline & & 0,342 & 0,117 & 0,099 & 0,028 \\
\hline \multicolumn{6}{|c|}{ ANOVA } \\
\hline \multicolumn{2}{|c|}{ Sum of Squares } & df & Mean Square & F & Sig. \\
\hline Regression & 0,010 & 2 & 0,005 & 6,445 & 0,002 \\
\hline Residual & 0,078 & 97 & 0,001 & & \\
\hline Total & 0,089 & 99 & & & \\
\hline \multicolumn{3}{|c|}{$\begin{array}{l}\text { Unstandardized } \\
\text { Coefficients }\end{array}$} & $\begin{array}{l}\text { Standardized } \\
\text { Coefficients }\end{array}$ & $\mathrm{T}$ & Sig. \\
\hline & B & Std. Error & Beta & & \\
\hline (Constant) & 0,302 & 0,025 & 11,974 & 0,000 & \\
\hline $\begin{array}{l}\text { Effective } \\
\text { Leadership }\end{array}$ & 0,018 & 0,008 & 0,225 & 2,359 & 0,020 \\
\hline $\begin{array}{l}\text { Ineffective } \\
\text { Leadership }\end{array}$ & $-0,016$ & 0,006 & $-0,252$ & $-2,645$ & 0,010 \\
\hline
\end{tabular}

a Dependent Variable: MEIS's full-scale Emotional Intelligence score

\section{DISCUSSION}

In line with the theoretical expectations, the results revealed that the individuals' level of emotional intelligence related significantly to what can be considered effective and ineffective leadership in terms of leadership behaviour and the outcomes of leadership. This supports the assumption that effective leadership may have its roots in managing emotions (Caruso et al., 2002).

The level of a leader's emotional intelligence determines whether or not such a leader is able to influence behaviour and take individual development into consideration by stimulating followers intellectually. An emotionally intelligent leader is able to instill trust and commitment, and motivate followers to exert extra effort, which in turn creates a feeling of satisfaction once the set goals are reached.

The research results indicate that Emotional Intelligence correlates positively with one Transactional Leadership component, namely Contingent Rewards. According to the principal component analysis results, Contingent Rewards appears to relate strongly to Effective Leadership behaviour. Contingent Rewards supports the reinforcement theory of motivation, which states that an individual's decisions concerning present behaviour are based largely on the consequences, or rewards, of past behaviour. Where past action has led to positive consequences, a person tends to repeat such actions (Steers et al., 1996). It has been found that contingent reward (reinforcement) is strongly related to job satisfaction and organizational commitment (Steers et al., 1996). Thus, 
contingent reward is strongly related to the needs of individuals and has strong emotional connotations. Although it may not be the intention of the leader to reward individuals at an emotional level, both satisfaction and commitment have emotional connotations. According to the research data, Contingent Rewards relates more strongly to Transformational Leadership than to Transactional Leadership. Visser (1992) specifically pointed out that there is a considerable overlap between Contingent Rewards items and the Transformational Leadership factor, Individualized Consideration. The notion that Contingent Rewards can be considered a component of Effective Leadership is confirmed by Barbuto and Brown (2000).

Argued from the Management by Exception (Passive) and Laissez-faire point of view, the results suggest that a leader with less Emotional Intelligence feels more comfortable with these leadership behaviours. As discussed earlier, both these types of leaders distance themselves from individual followers. An emotionally unaware or unintelligent leader finds it difficult to identify, use or manage the emotions associated with individual and group sessions. This includes emotions associated with conflict situations, as well as positive emotions, which support individual commitment and inspiration. It can be argued that such a leader finds it difficult to instill vision, to motivate and to inspire, to transform people to higher levels of performance, to communicate trust and emotional support and to influence behaviour, as he/she has difficulty in getting involved in an individual follower's emotional sphere.

It is therefore concluded that emotional intelligence relates significantly to leadership behaviour and the outcomes of leadership that are considered either effective or ineffective in a rapidly changing environment. Firstly, the level of emotional awareness and the management of emotions in oneself and others influences the level of commitment and involvement of a leader with an individual follower. This involvement enables a leader to influence the behaviour of an individual follower in order to develop the person to rise to higher levels of performance. Such a leader is able to instill trust and commitment, as he/she understands the underlying emotions associated with individual behaviour. Secondly, such a leader is able to inspire followers to exert extra effort, which in turn results in a higher level of satisfaction for followers.

One of the limitations of the study was that the reliability coefficients of the MLQ5X were significantly lower than expected for the particular research sample and ranged between unacceptable and acceptable. The main reason for the low reliabilities could be the length of the scales the shortened version of the MLQ5X was used for the purposes of this research. Low score variance and a homogeneous sampling group could also be the reason for the low reliabilities.

A further limitation of the study was the extent to which the sample was representative of the total population of South African managers. The sample can be considered one-sided in terms of the representation of race and home language groups.

In view of findings, the following recommendations are made:

1. Further studies should include a larger sample size that represents the South African leadership corps better in terms of race and language groups.

2. The data should include a $360^{\circ}$ evaluation of a leader's leadership behaviour so one can investigate whether the perceptions of followers and significant others matches those of the leader.

\section{REFERENCES}

Ackermann, C.P., Schepers, J.M., Lessing, B.C. \& Dannhauser, Z. (2000). Die faktorstruktuur van Bass se veelfaktorleierskapsvraelys in die Suid-Afrikaanse konteks. Tydskrif vir Bedryfsielkunde, 26 (2), 58-65.

Barbuto, J.E. \& Brown, L.L. (2000). Full range leadership. Retrieved February 2, 2002, from the World Wide Web: http://ianrwww.unl.edu/pubs/ consumered/g1406.htm.

Bass, B.M. (1985). Leadership and performance beyond expectations. New York, NY: Free Press.

Bass, B.M. \& Avolio, B.J. (1992). Many roads lead to transformational leadership. New York, NY: Free Press.

Bass, B.M. \& Avolio, B.J. (1993). Transformational leadership: A response to critics. In Chemers, M.M. \& Ayman, R. (Eds.). Leadership theory and research: perspectives and directions. San Diego, CA: Academic Press.

Bass, B.M. \& Avolio, B.J. (1994). Improving organizational effectiveness through transformational leadership. Thousand Oaks, CA: Sage.

Bass, B.M. \& Avolio, B.J. (1997) Full Range Leadership Development: Manual for the Multifactor Leadership Questionnaire. Redwood City, CA: Mind Garden.

Bass, B. M. \& Avolio, B. J. (2000). Technical report, leader form, rater form, and scoring key for the MLQ Form 5x-short. Binghamton, NY: Center for Leadership Studies, Binghamton University.

Bliss, S.E. (2000). The effect of emotional intelligence on a modern organizational leader's ability to make effective decisions. Unpublished master's thesis, Bellevue University, Nebraska.

Caruso, D., Mayer, J.D. \& Salovey, P. (2002). Emotional intelligence and emotional leadership. In R. Riggio \& S. Murphy \& F. J. Pirozzolo (Eds.). Multiple Intelligences and Leadership. Mahwah, NJ: Lawrence Erlbaum.

Cavallo, K. (2000). Emotional competence and leadership excellence at Johnson \& Johnson: the emotional intelligence and leadership study. Retrieved September 20, 2003, from the World Wide Web: http:// corpconslutinggroup.com.

Cohen, J. (1977). Statistical power analysis for the behavioral sciences. (Revised Edition). New York, NY: Academic Press.

Colvin, R.E. (1999). Transformational leadership: a prescription for contemporary organisations. Unpublished Article.

Drucker. P.F. (1996). The leader of the future: new visions, strategies and practices for the next era. San Francisco, CA: Jossey-Bass.

Hanke, M. (1998). Reliability of MLQ5X scales. CEST 1998. Retrieved September 30, 2003, from the World Wide Web: http://wuwien.ac.at/inst/or/geyer/ap3/node10.html.

Horn J.L. (1965). A rationale and test for the number of factors in factor analysis. Psychometrika, 30 (2), 179-185.

Hooper, A. \& Potter, J. (2000). Intelligent leadership: creating a passion for change. London: Random House.

Kim, J. and Mueller, C.W. (1978). Factor Analysis: Statistical methods and practical issues. Sage University Paper series on Quanitative Applications in the Social Sciences, series no 07014. Beverly Hills and London: Sage.

Kuruppuarachchi, P.R. (2001). How IT project managers are leading change. Management Services, December, 8-9.

Lewis, P.S., Goodman, S.H. \& Fandt, P.M. (1998). Management: challenges in the 21st century. Cincinnati: Thomson.

Liontos, L.B. (1992). Transformational Leadership. Eric Digest, 72. Retrieved September 30, 2003, from the World Wide Web: http://ed.gov/database/ERIC_Digests/ed347636.html.

Lowe, K.B., Kroeck, K.G. \& Sivasubramaniam, N. (1996). Effectiveness correlates of transformational and transactional leadership: a meta-analytic review of the MLQ5X literature. Leadership Quarterly, 7 (3), 385-425.

Mayer, J.D. \& Salovey, P. (1997). What is emotional intelligence? In P. Salovey \& D. Sluyter (Eds). Emotional Development and Emotional Intelligence: Implications for Educators. New York, NY: Basic Books. 
Mayer, J.D., Salovey, P. \& Caruso, D. (2000). Models of emotional intelligence. In R.J. Sternberg, (Ed). Handbook of Intelligence. Cambridge: Cambridge University Press.

McLeod, W.T. \& Hanks, P. (1984). Collins concise dictionary of the English language. Oxford: Oxford University Press.

Nanus, B. (1992). Visionary leadership: creating a compelling sense of direction for organisations. San Fransisco, CA: Jossey-Bass.

Robbins, S.P. (1998). Organisational behaviour. Englewood Cliffs, NJ: Prentice Hall.

Ryback, D. (1998). Successful leadership is more than IQ: putting emotional intelligence to work. Boston, MA: ButterworthHeinemann.
Steers, R.M., Bigley, G.A. \& Porter, L.W. (1996). Motivation and leadership at work. Singapore: McGraw-Hill.

Steiner, C. \& Perry, P. (1999). Achieving emotional literacy. London: Bloomsbury.

Swart, J.P. (1985). A comparison of the current situational leadership theories. Unpublished Masters Thesis. University of Pretoria, Pretoria.

Visser, W.A. (1992). Replication factor analysis of the Bass Multifactor Leadership Questionnaire. Department of Psychology, University of Cape Town.

Weisinger, H. (1998). Emotional intelligence at work. San Francisco, CA: Jossey-Bass. 